\title{
B Acute Lymphoblastic Leukemia with $\mathrm{t}(4 ; 11)(\mathrm{q} 21 ; 23)$
}

National Cancer Institute

\section{Source}

National Cancer Institute. B Acute Lymphoblastic Leukemia with t(4;11)(q21;23). NCI

Thesaurus. Code C162776.

A B-cell acute lymphoblastic leukemia associated with $\mathrm{t}(4 ; 11)(\mathrm{q} 21 ; 23)$. This translocation leads to the generation of the fusion gene MLL-AF4. 